\title{
Geomorphology and soil evolution of a moving dune system in south-west Spain (Doñana National Park)
}

\author{
P. A. Siljeström and L. E. Clemente*
}

Accepted 21 March 1989

\begin{abstract}
A detailed geomorphological study has been made of the moving dune system in the Donana National Park and the system differentiated into 'morphoedaphic elements'. These are considered the simplest units composing the landscape, in which a strong relationship can be observed between the soils and the characteristic vegetation. Parallel to the recognized morphoedaphic elements, the soils evolve as a result of two processes: hydromorphy and substratum stabilization. Finally, a common evolutionary soil-geomorphology catena is established.
\end{abstract}

\section{Introduction}

The area studied lies in the Doñana National Park, which is on the right bank of the mouth of the Guadalquivir River (SW Spain) (Fig. 1). From a geomorphological point of view, Doñana National Park can be divided into three morphogenetic systems: estuarine, littoral and aeolian (Siljeström \& Clemente, 1987). The aeolian system is formed by sands produced through erosion of the plio-Quaternary coastal cliff. These sands are carried by littoral drift (Ménanteau, 1981) and, later, are mobilized by the action of wind. Two geomorphological units can be differentiated within this system: stabilized dunes and moving dunes.

The moving dunes occupy a narrow strip in the SW of the Park, run parallel to the coast, and are approximately $30 \mathrm{~km}$ long and $4 \mathrm{~km}$ wide. They begin $5 \mathrm{~km}$ SE of 'Torre la Higuera' in Matalascañas where the stabilized dunes (which they partially cover) disappear, and end at the mouth of the Guadalquivir River. This geomorphological unit is formed by three or four well-differentiated dune fronts, with varying speeds of movement and height. The dune fronts advance in a SW-NE direction over a base of soggy sand, moistened by the water table. The directon of movement is that of the dominant wind. Long deflated paths or passages (slacks) are left between them (Siljeström, 1985). The dune complex is of interest on account of its complicated dynamics and good state of conservation. It is considered to be Spain's most important dune system, and one of the most remarkable in Europe (Ranwell, 1972). Nevertheless, plans for urbanization (roads, towns, industries, etc.) seriously threaten it.

\section{Climate}

Climatic features of the Doñana National Park are shown in Fig. 2 for a 20 -year period (1964-1983). Even though the temperature is quite regular between years, the rainfall

"Instituto de Recursos Naturales y Agrobiologia de Sevilla. CSIC. Apartado 1052. 41080 Sevilla, Spain. 


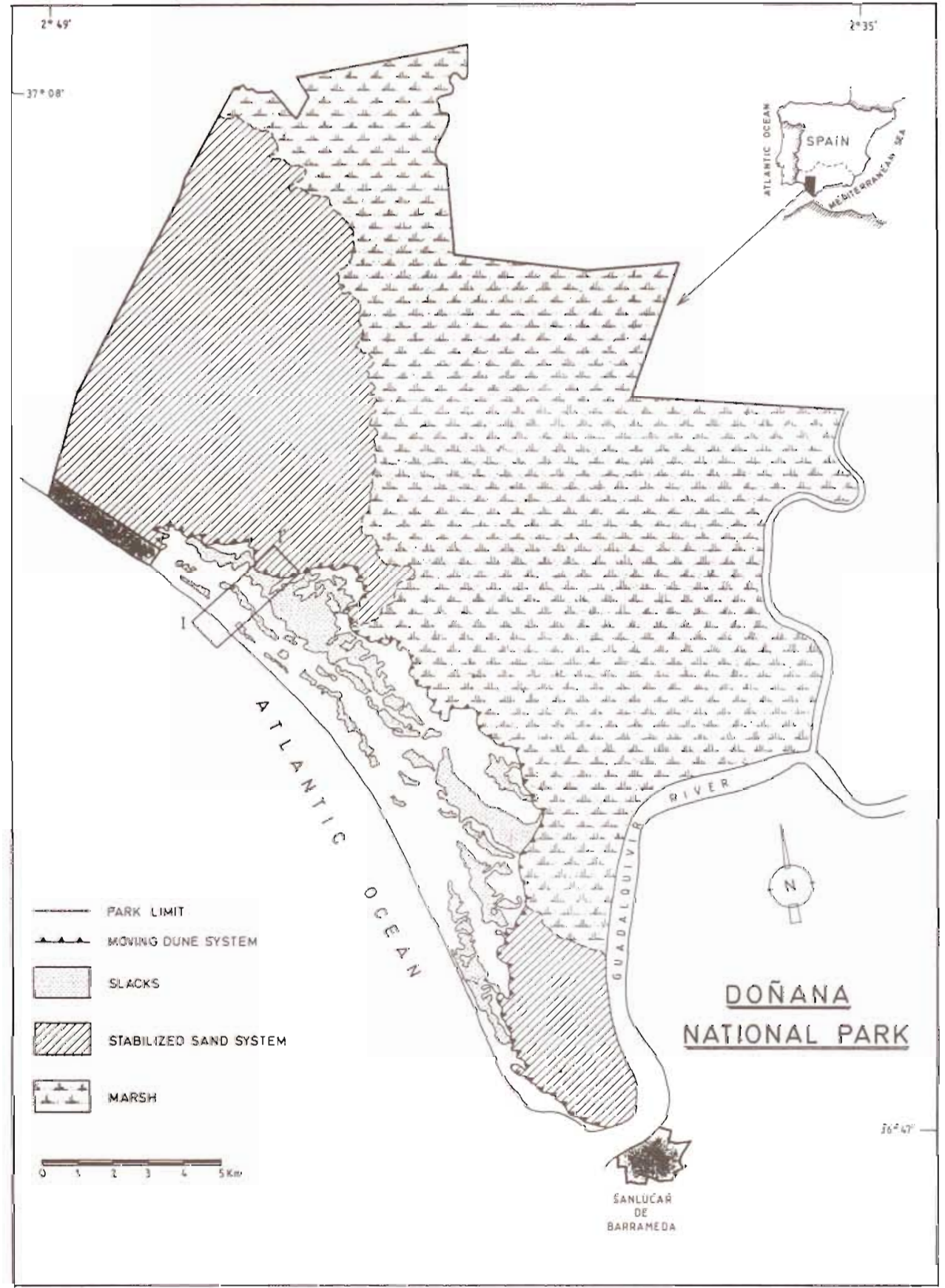

Figure 1. Doñana National Park 

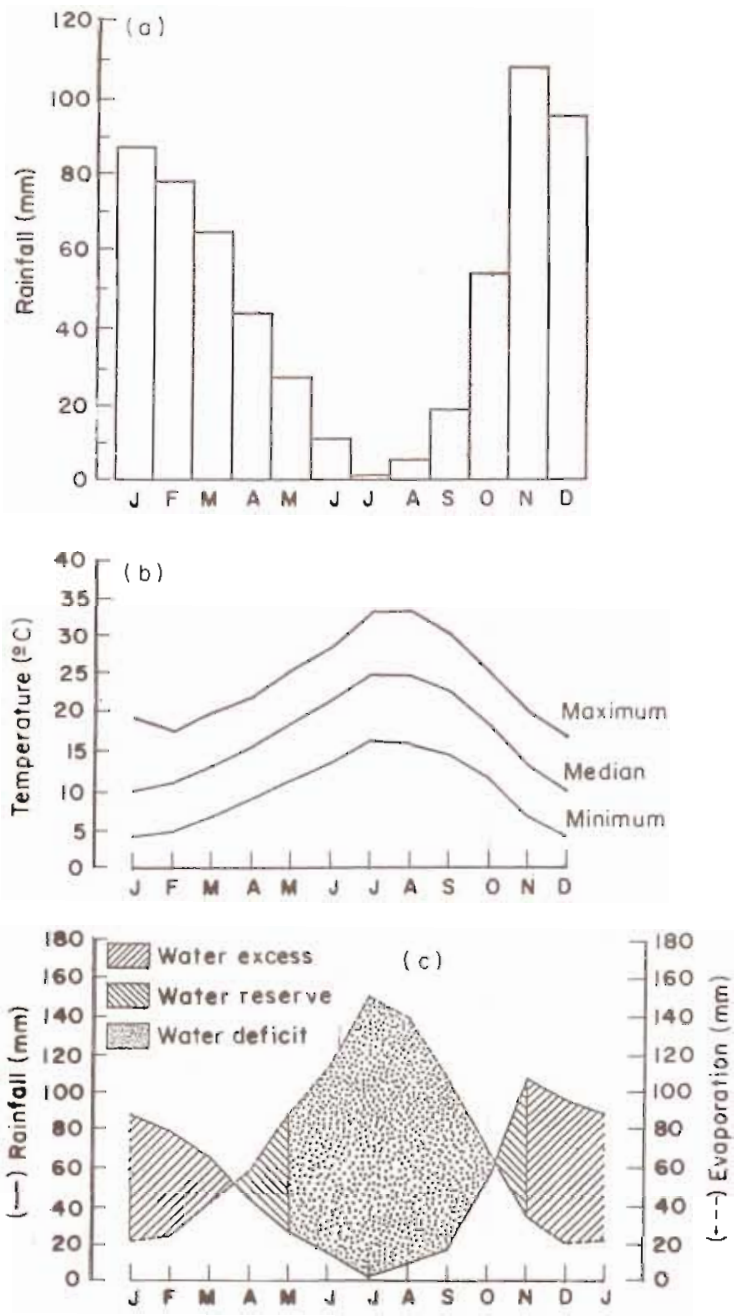

Figure 2. Climatic data (Doñana National Park, 1964-1983). (a) Average monthly rainfall; (b) average maximal, median and minimal temperatures $\left({ }^{\circ} \mathrm{C}\right)$; (c) water balance.

[Fig. 2(a)] shows the variability characteristic of a Mediterranean climate. The average annual rainfall $(541.8 \mathrm{~mm})$ has little or no significance as a parameter in soil genesis. In some years, the total rainfall is even less than $300 \mathrm{~mm}$, while during others it can exceed $700 \mathrm{~mm}$. The irregular rainfall distribution is apparent not only between years, but also during them. In fact, $50 \%$ of the total precipitation falls during winter, while, in summer, a level of 5\% is seldom reached (Clemente \& Siljeström, 1989).

The temperature data indicate a climate characterized by a short and mild winter, when it is seldom below $0^{\circ} \mathrm{C}$, and a long warm summer when temperatures over $40^{\circ} \mathrm{C}$ are quite common-sometimes reaching maximum values of $45-47^{\circ} \mathrm{C}$ in July and August. These temperature differences are reflected in the monthly averages [Fig. 2.(b)]. Extremely high temperatures and scarce rainfall cause a deficit of water in summer, and rainfall that exceeds evapotranspiration occurs only during 3-4 months of the year [Fig. 2(c)]. The climate in the Donana National Park is classified as dry subhumid, with water excess in winter (Thorntwaite, 1948). 


\section{Geomorphological evolution.}

The moving dunes complex constitutes the second geomorphological unit within the aeolian morphogenetic system. Its origin is in the sand transported by littoral drift in a NW-SE direction, capable of shifting up to $300,000 \mathrm{~m}^{3}$ of sediment a year. (Subdirección de Costas, 1977). These sands result from erosion of the plio-Quaternary cliff located NW of Matalascañas. The cliff is made up of loose sandstone, broken up by numerous gullies after the spring tides (Vanney \& Ménanteau, 1979).

The disappearance of the coastal cliff and the burial of the stabilized dunes by moving dunes, suggests a morphological fault with a $\mathrm{N}-\mathrm{S}$ axis that may go through Matalascañas. This would cause subsidence of the right bank of the mouth of the Guadalquivir River, provoking a double effect (Ménanteau \& Clemente, 1977). On the one hand, the dunes located west of Matalascañas are stabilized because they receive no new sediment to overcome the slope of the coastal cliff. On the other, to the east, the sea erodes ancient dunes which are afterwards covered by new fronts and constitute the present-day moving dunes system.

The system is composed of up to four advancing dune fronts, leaving between them long deflation paths or passages, whose bottoms are related to the depth of the water table. On the basis of its dynamics, this system has been subdivided into three subunits which can clearly be differentiated in aerial photographs: dune fronts, slacks and gusanos (a local name meaning 'worms'). As these three subunits are closely related in their origin and functions, their dynamics will be discussed as a whole (Fig. 3).

Embryonic dunes, appear near and parallel to the coast line: they are characterized by their small size and great mobility. The first mounds of sand are fixed by scanty vegetation. Once these reach a certain height, they begin to form a continuous dune front approximately $200 \mathrm{~m}$ from the coast line. The process of formation has been described by Paul (1944). The first dune front advances, loses speed, and is then reached by younger, more recent dunes, thus forming regular ridges. According to the classifications of Davies (1980) and McKee (1979), the interior dunes can be described as asymmetric and transgressive, or parabolic with atypical morphology, since they are much wider than they are long.

Their asymmetry is due to differences in slope at the dune front (up to $45^{\circ}$ ) and at the tail (from $3^{\circ}$ to $5^{\circ}$ ) (Garcia Novo et al., 1975). The advancing slope varies in proportion to the height of the dunes, since an increase in height gives the sand at the crest more stability (Torres et al., 1977). In general, the height of the front varies along a gradient from the coast towards the marsh, where maximum values are found $(30 \mathrm{~m}$ in 'Cerro de los Ansares').

The movement of the dunes is irregular, since it is conditioned by vegetation, depth of the water table, and incidence of wind. It was quantified by Garcia-Novo et al. (1975) using several methods (multitemporal analysis of aerial photographs, distance/pine-age relationship, etc.). The average speed has been calculated at $5 \mathrm{~m} /$ year. However, over short periods, the variability increases, an'd 'fast' and 'slow' sectors, which alternate over the years, can be differentiated. As the scale is reduced, the effect of the vegetation becomes apparent through the recesses and festooned shapes that appear.

The movement of the dune fronts is similar to that described by Hoyt (1966) for the dunes in the Namib Desert (SW Africa). The sand may settle on the leeward or advancing slope in three ways: (a) Part of the sand is transported up the crest, falling directly on the leeward slope. (b) Part is deposited on the crest, where it accumulates until it reaches the point of disequillibrium and collapses in avalanches (Fig. 4). (c) Finally, eddies developed leeward, push the sand at the surface and transport it to the advancing slope. The last process is the least important from a volumetric point of view, although it must be taken into account in a morphological and grain-size study since it keeps the surface ahead of the advancing front relatively clean.

The second distinguishable element in the moving dune system are the slacks or 


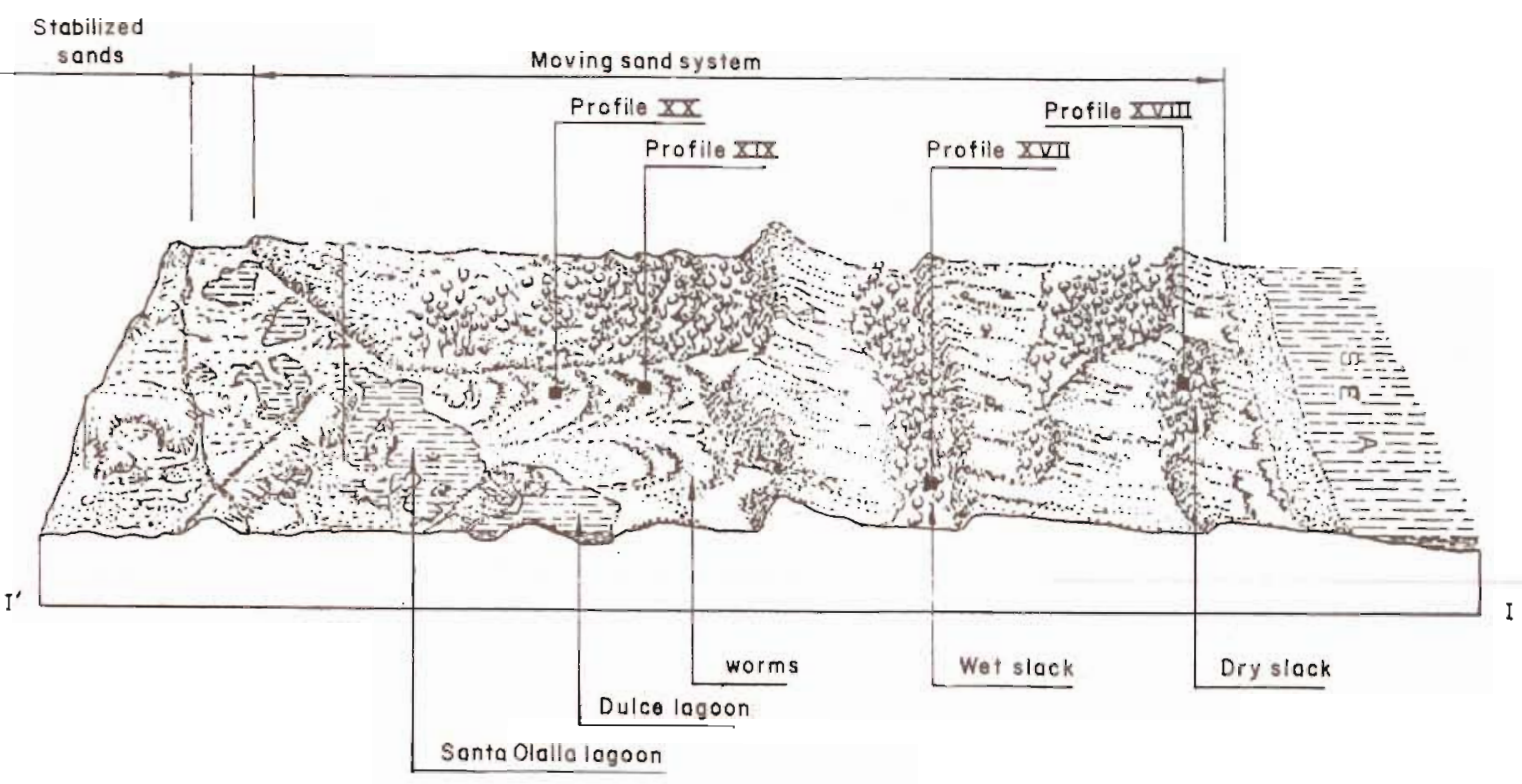

Figure 3. Block diagram, I-I', and profile. 


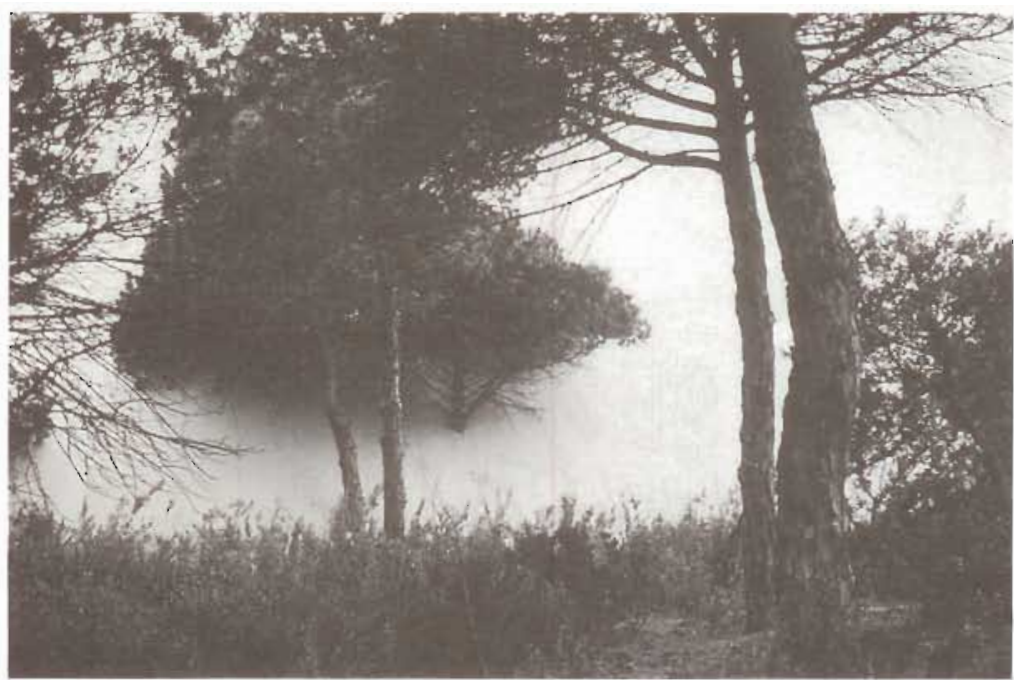

Figure 4. Dune front from across a wet slack.

'corrales'. These are interdunar valleys with flat bottoms found between the moving fronts (Figs 3,4$)$. Their origin is related to the depth of the water table since they are formed by erosion of the dune tail. As the dune approaches the water table the sands, moistened by capillarity, get soggy and cannot be mobilized by wind (Torres er al., 1977). The final result is an eroded surface, almost horizontal, which favours soil formation and colonization by vegetation. The dimensions of the slacks, like those of the dunes, are variable and depend on the speed at which the fronts advance over them. The most extensive dunes reach a length of $7000 \mathrm{~m}$ and a width of $600 \mathrm{~m}$ ('Corral de Zalabar'), or a length of $4000 \mathrm{~m}$ and a width of $800 \mathrm{~m}$. ('Corral de la Liebre'), although these dimensions are exceptional. Breaking up of long slacks by 'fast sectors' is frequent. The slacks show in evolution gradient from the coast to the interior. Those situated close to the littoral are 'dry slacks' above a deep water table. The 'wet slacks', above a shallow water table which can even reach the surface in the wet season, show greater stability. This permits the establishment of well-adapted vegetation (Figueroa, 1976).

From an hydrogeological point of view, the slacks constitute one of the principal discharge areas of the dune aquifer through evapo-transpiration from the surface water sheet (Vela, 1984). This aquifer is important because it acts as an hydraulic barrier and prevents, substantial discharge into the ocean. It is refilled basically by rain water filtering through the dunes. On the basis of the sand permeability and the characteristics of the dune aquifer, Vela (1984) has calculated the age of the water which arises in the slacks as between 1 and 60 years. The soil shows different characteristics (accumulation of salts and/ or iron oxides) along the slacks, according to the levels of the ground water. In general, the slack bottom lies between 3 and $10 \mathrm{~m}$ above sea level. This height varies within the slacks, since small sandy hills $(0.5 \mathrm{~m}$ to $1 \mathrm{~m}$ in. height) form parallel undulations between them (Garcia-Novo et al., 1975). These low, sandy hills are called 'worms' (gusanos). Their origin is controversial. Vanney \& Ménanteau (1979) define them as 'interdunes', while Zazo (1980) assumes that they are the remains of old barkans (Fig. 3). Allier et al. (1974) and Allier et al. (1975), describe them as being similar to the Gegenwällen described by Paul (1944). Garcia-Novo et al. (1975), however, agree that these structures result from fixation of the dune tail by seasonal variations in the water table. During dry periods the level of the water table deepens and the dune tail begins to move forward. It leaves behind it a small hillock which is stabilized by the vegetation generated during the wet season, and 
which retains the form of the preceding dune (Fig. 5). These gusanos or 'worms' lie parallel to the end of the dune tail. They are especially conspicuous at the western and southwestern edges of the permanent lagoons (Santa Olalla, Sopeton, etc.), because the dune which formed them has disappeared into the lagoons (Fig. 6). Their decrease during the last 200 years supports this hypothesis (data collected at the Medina-Sidonia Ducal Arquives by Granados, 1981).

Coarse sand predominates over fine (International Scale) (Apcarian, 1983). The differences which appear are small and more closely related to local topography than to distance from the beach. The finest sand is found in low areas, where thicker vegetation favours its accumulation. Analysis of the sands shows a predominance of primary minerals (mostly quartz) which had already been greatly weathered when deposited. The prevailing heavy transparent minerals are andalucite-turmaline-epidote with some zircon. The predominance of this group, and the presence of staurolite, garnet and distena, indicate an origin from metamorphic rocks, like granite, pegmatite, and other igneous rocks which are quire common in Sierra Morena (Pérez-Mateos \& Ribas, 1961).

The most important unstable mineral is epidote (Apcarián, 1983). The presence of this mineral in small quantities in the sediments of the coastal cliff leads us to believe that there has been contamination by more modern sands from rivers located to the west (Guadiana, Piedras, Tinto and Odiel), which are transported by littoral drift in a W-E direction (Apcarián, 1983). The sand along a transect: perpendicular to the coast shows a mineral distribution based on density but strongly influenced by topography. Mineral distribution seems to be more closely related to the topography than to the transect distance.

\section{Soil evolution}

Soil evolution in the moving sand is greatly conditioned by the mobility and the quartz nature of the parent material. The result is a profile that is little developed. Only a 'C' horizon can be differentiated. In the slacks (interdunar valleys), the water table restrains the mobility of the substratum, thus permitting a degree of evolution and profile development based on hydromorphic processes. The varying depths of the water table in the slacks characterize the two morphoedaphic elements of this subunit: wet slacks and dry slacks, represented by profiles XVII and. XVIII, respectively (Table 1).

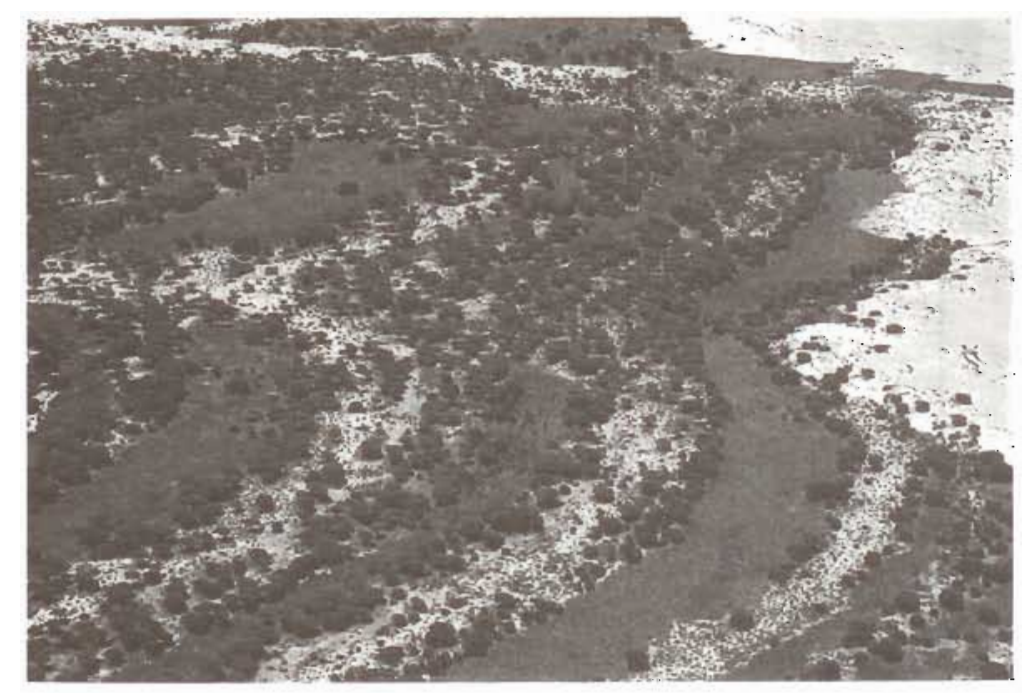

Figure 5. Aerial view of the 'worms' (gusanos). 
Table 1. Morphological description of profile, physical and chemical characteristics

\begin{tabular}{|c|c|c|c|c|c|c|c|c|c|c|c|c|c|}
\hline \multirow[b]{2}{*}{ Profile } & \multirow{2}{*}{$\begin{array}{l}\text { Depth } \\
(\mathrm{cm})\end{array}$} & \multirow[b]{2}{*}{ Horizon } & \multirow{2}{*}{$\begin{array}{l}\text { (h) } \\
\text { Colour }\end{array}$} & \multirow{2}{*}{$\begin{array}{c}(\mathrm{h}) \\
\text { Mottles }\end{array}$} & \multirow{2}{*}{$\begin{array}{c}\% \\
\text { M.O. }\end{array}$} & \multirow[b]{2}{*}{$\mathrm{C} / \mathrm{N}$} & \multirow{2}{*}{$\begin{array}{c}\mathrm{H}_{2} \mathrm{O} \\
\mathrm{pH}\end{array}$} & \multirow{2}{*}{$\begin{array}{c}\mathrm{meq} / 100 \mathrm{~g} \\
\text { CEC }\end{array}$} & \multirow{2}{*}{$\begin{array}{l}\% \\
\mathrm{~V}\end{array}$} & \multicolumn{2}{|c|}{$\mathrm{Fe}_{2} \mathrm{O}_{3}(\%)$} & \multirow[b]{2}{*}{ Free/total } & \multirow[b]{2}{*}{ Texture } \\
\hline & & & & & & & & & & Total & Free & & \\
\hline \multirow[t]{4}{*}{ XVII } & $0-2$ & $\mathrm{Au}_{1}$ & 5 YR $2,5 / 2$ & - & $6 \cdot 1$ & $11 \cdot 4$ & $5 \cdot 8$ & $7 \cdot 3$ & $79 \cdot 4$ & $1 \cdot 58$ & $0 \cdot 70$ & $44 \cdot 3$ & Sandy \\
\hline & $2-7$ & $\mathrm{Au}_{2} \mathrm{~g}$ & 10 YR $4 / 4$ & 7,5 YR 5/6 & $1 \cdot 6$ & $10 \cdot 3$ & $5 \cdot 9$ & $3 \cdot 2$ & $78 \cdot 1$ & $1 \cdot 19$ & $0 \cdot 32$ & $26 \cdot 9$ & Sandy \\
\hline & $7-20$ & $\mathrm{Cg}_{1}$ & $10 \mathrm{YR} 6 / 3$ & 5 YR 4/6 & 0.4 & $7 \cdot 7$ & $5 \cdot 9$ & $1 \cdot 0$ & - & 0.97 & 0.13 & $13 \cdot 4$ & Sandy \\
\hline & $20-55$ & $\mathrm{Cg}_{2}$ & $\begin{aligned} & 10 \mathrm{YR} 6 / 3 \\
+ & 10 \mathrm{YR} 5 / 1\end{aligned}$ & 2,5 YR $3 / 0$ & $0 \cdot 2$ & $6 \cdot 0$ & $5 \cdot 7$ & 0.9 & - & $1 \cdot 28$ & 0.12 & $9: 4$ & Sandy \\
\hline \multirow[t]{2}{*}{ XVIII } & $0-3$ & $\mathrm{O}$ & 7,5 YR $3 / 2$ & - & $16 \cdot 1$ & $34 \cdot 6$ & $6 \cdot 2$ & $19 \cdot 0$ & $78 \cdot 9$ & 0.67 & 0.49 & $73 \cdot 1$ & Sandy \\
\hline & 3 & $\mathrm{C}$ & $10 \mathrm{YR} 7 / 2$ & 10 YR $5 / 8$ & 0.4 & $7 \cdot 7$ & $6 \cdot 4$ & $1 \cdot 0$ & $70 \cdot 0$ & $0 \cdot 16$ & 0.97 & $43 \cdot 7$ & Sandy \\
\hline \multirow[t]{5}{*}{ XIX } & $0-15$ & A & 10 YR $5 / 4$ & $5 \mathrm{Yr} 3 / 3$ & 0.6 & $8 \cdot 8$ & $6 \cdot 5$ & $1 \cdot 5$ & $66 \cdot 7$ & 1.79 & $0 \cdot 14$ & $7 \cdot 8$ & Sandy \\
\hline & $15-30$ & AC & 10 YR $6 / 4$ & 10 YR $6 / 8$ & 0.4 & $7 \cdot 7$ & $6 \cdot 7$ & 1.0 & 80.0 & $4 \cdot 65$ & 0.27 & $5 \cdot 8$ & Sandy \\
\hline & $30-70$ & $\mathrm{C}_{1}$ & $10 \mathrm{YR} 5 / 1$ & - & $0 \cdot 2$ & $6 \cdot 0$ & $6 \cdot 8$ & $1 \cdot 0$ & $80 \cdot 0$ & 0.89 & $0 \cdot 14$ & $15 \cdot 7$ & Sandy \\
\hline & $70-160$ & $\mathrm{C}_{1} \mathrm{~g}$ & 10 YR 5/2 & $10 \mathrm{YR} 5 / 6$ & $0 \cdot 2$ & $6 \cdot 0$ & $7 \cdot 3$ & 1.0 & $90 \cdot 0$ & $2 \cdot 40$ & 0.17 & $7 \cdot 1$ & Sandy \\
\hline & $160-$ & $\mathrm{C}_{2}$ & $10 \mathrm{YR} 5 / 3$ & - & 0.2 & $6 \cdot 0$ & $7 \cdot 8$ & 0.8 & $100 \cdot 0$ & $1 \cdot 27$ & 0.08 & $6 \cdot 3$ & Sandy \\
\hline \multirow[t]{5}{*}{$\mathrm{xx}$} & $0-15$ & A & 2,5 YR $3 / 2$ & - & $11 \cdot 4$ & $20 \cdot 7$ & $5 \cdot 7$ & $10 \cdot 0$ & $68 \cdot 0$ & $13 \cdot 04$ & $11 \cdot 70$ & $89 \cdot 7$ & Loamy-sandy \\
\hline & $15-30$ & $\mathrm{ACg}$ & 10 YR $5 / 4$ & 10 YR 5/8 & 0.5 & $9 \cdot 7$ & $6 \cdot 7$ & $1 \cdot 5$ & $80 \cdot 0$ & $2 \cdot 92$ & $0 \cdot 44$ & $15 \cdot 1$ & Sandy \\
\hline & $30-60$ & $\mathrm{Cg}_{1}$ & $10 \mathrm{YR} 4 / 4$ & $5 \mathrm{YR} 5 / 8$ & 0.3 & $8 \cdot 5$ & $6 \cdot 6$ & 1.5 & $80 \cdot 0$ & 5.51 & $0 \cdot 30$ & $5 \cdot 4$ & Sandy \\
\hline & $60-70$ & $\mathrm{Cg}_{2}$ & $10 \mathrm{YR} 4 / 1$ & 10 YR 5/8 & $0 \cdot 2$ & 6.0 & $7 \cdot 0$ & $1 \cdot 0$ & $90 \cdot 0$ & $5 \cdot 50$ & $0 \cdot 20$ & $3 \cdot 6$ & Sandy \\
\hline & $70-100$ & $\mathrm{Cg}_{3}$ & $2,5 \mathrm{Y} 4 / 2$ & $10 \mathrm{YR} 5 / 1$ & $0 \cdot 2$ & $6 \cdot 0$ & $8 \cdot 1$ & $1 \cdot 0$ & $100 \cdot 0$ & $4 \cdot 30$ & $0 \cdot 18$ & $4 \cdot 5$ & Sandy \\
\hline
\end{tabular}



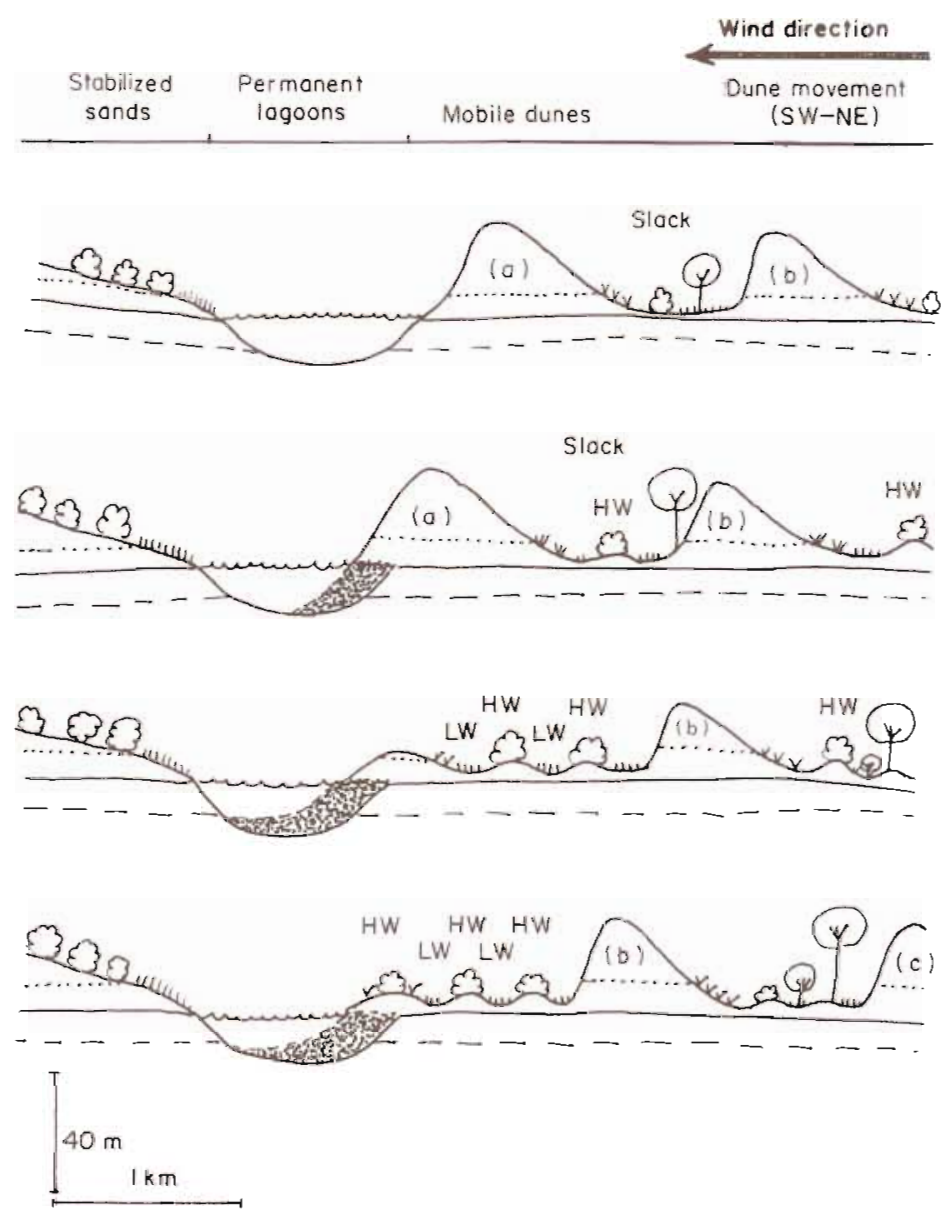

Figure 6. Hypothesis of the 'worm.' origin in the mobile dune system. ( . . . .) Influence of the highest level reached. by the water table; (__ (- - - - ) lowest level reached by the water table (summer); (a), (b) (c) dunes; HW, high 'worm'; LW, low 'worm".

Profile XVII remains saturated throughout most of the year. Even in the dry season the water table is at a depth of only $50 \mathrm{~cm}$. The hydrophilous vegetation that grows on this soil is made up basically of dystrophic rushes which contribute little to the organic matter content $(6 \cdot 1 \%$ in Au). The organic horizon is very thin $(7 \mathrm{~cm})$ and shows signs of hydromorphy,

Based on the values of the $\mathrm{C} / \mathrm{N}$ rate (near 10), $\mathrm{pH}$ (around 6) and base saturation (80\%), the humus can be classified as 'forestal', subtype 'hydromull' (Duchaufour, 1975). Beneath this, a grey color with mottling and a slight sapric odor can be observed. This indicates reducing conditions which define an aquic system. The organic horizon is so thin that there is no epipedon, so the soil is classified as an entisol with an aquic moisture regine (Aquent) (Soil Taxonomy, 1975). The sandy texture of the profile and the fulfilment of the Great Group conditions shows it to be a Typic Psammaquent (Soil Taxonomy, 1975).

Profile XVIII indicates a typical 'dry slack' soil, with the water table always more than $2 \mathrm{~m}$ deep. The vegetation is an open pine grove with little brushwood development. The pine grove provides organic matter, which accumulates on the ' $\mathrm{C}$ ' horizon without combining with mineral material. This results in the formation of an ' $\mathrm{O}$ ' Horizon $3 \mathrm{~cm}$ 
thick, containing $16.5 \%$ organic matter, which abruptly decreases to $0.4 \%$. The high $\mathrm{C} / \mathrm{N}$ rate (34.6), climatic conditions and ' $\mathrm{O}$ ' Horizon morphology indicate a humus that has developed little and which can be classified as 'xeromor' (Duchaufour, 1975). As in the previous profile, the poorly developed soil is an entisol: a psamment because of its texture and a xeropsamment because of its moisture regime. Finally, as it fulfils the basic concept: of the Great Group, it can be classified as aquic xeropsamment.

The 'worms' (gusanos) can be divided into two morphoedaphic elements: high 'worms" and low 'worms', on the basis of their microtopography and the intensity of the hydromorphy process. These elements are shown by profiles. XIX and XX, respectively (Table 1). Profile XIX ('high worm') corresponds to an undeveloped soil, where only an 'A' horizon, poor in organic matter ( $(0.6 \%)$ can be distinguished. The low values of organic ' $\mathrm{C}$ ' $(0 \cdot 35 \%)$ and the $\mathrm{C} / \mathrm{N}$ rate $(8 \cdot 8)$ indicate mineralization of the humus, so that it can be classified as 'scarcely developed forestal mull' (Duchaufour, 1975). A peculiar characteristic of these soils is the presence of thin, black strata of fine-size grains, parallel to the surface and spatially discontinuous. These grains are accumulations of heavy metals, mostly limenite, which vary the total $\mathrm{Fe}_{2} \mathrm{O}_{3}$ content in the different horizons, some of these reaching up to $4 \cdot 65 \%$ (AC). The water table, which is relatively near the surface during the wet season $(70 \mathrm{~cm})$, causes a mottling in the lower half of the profile. The soil is an entisol and, because of its sandy texture and xeric moisture regime, belongs to the Xeropsamment Great Group. In addition, because of its budding hydromorphy it can be defined as an Aquic Xeropsamment.

The soil from the 'low worm' (profile XX) suffers seasonal swamping. The higher position of the water table originates gleyzation horizons. At the same time, the establishment of dense vegetation (mostly rushes and grasses) is favoured. This results in a thick ' $\mathrm{A}$ ' horizon $(15 \mathrm{~cm})$, with a high content of organic matter $(11 \cdot 4 \%)$. The chemical

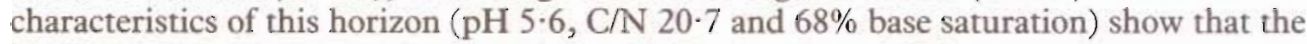
humus is 'forestal mull, subtype hydromull' (Duchaufour, 1975).

The total $\mathrm{Fe}_{2} \mathrm{O}_{3}$ and free- $\mathrm{Fe}_{2} \mathrm{O}_{3}$ content in the upper horizon $(13.04 \%$ and $11.70 \%$, respectively) is found in areas where there is upwelling of the water table (Siljeström et al., 1987). At a greater depth, the total $\mathrm{Fe}_{2} \mathrm{O}_{3}$ values continue to be high, some of them reaching $4 \%$, while free- $\mathrm{Fe}_{2} \mathrm{O}_{3}$ values decrease to around $0 \cdot 20 \%$. These variations indicate well-crystalized heavy minerals deeper in the soil. The deep and superficial horizons show strong weathering and upward leaching of oxides, which accumulate on the surface. The young age and lack of differentiation of the soil classifies it as an entisol and, since it has an aquic moisture regime, it belongs to the aquents. The sandy texture defines the soil as psammaquent, and the trend of the organic horizon to form a mollic epipedon, although it does not reach its thickness, classifies it as a mollic psammaquent.

\section{Conclusion}

The moving dune system is divided into three subunits: dune fronts, slacks and 'worms'. The last two can be subdivided into simpler units which are closely related to the soil evolution. These are called 'morphoedaphic elements'. The quartzitic nature of the parent material and its mobility condition the soil development. This is shown by the scarcely evolved catenas. These are at first represented by embryonic soils located in advancing dune fronts, while the final steps are the more depressed areas (low 'worms').

When the water table is deep enough, the mobility of the dunes prevents soil processes from acting. When the water table halts the sands, vegetation grows, fixing the substratum. Closely related to this appear undeveloped soils (typic xeropsamments). As the humidity increases, a hydromorphological process begins, at first affecting only the profile base (aquic xeropsamments). Later on, it affects all the horizons (typic psammaquents). Finally, as the humidity reaches a maximum, dense vegetation is favoured, so that the superficial horizon shows a trend towards the formation of a mollic epipedon (mollic 


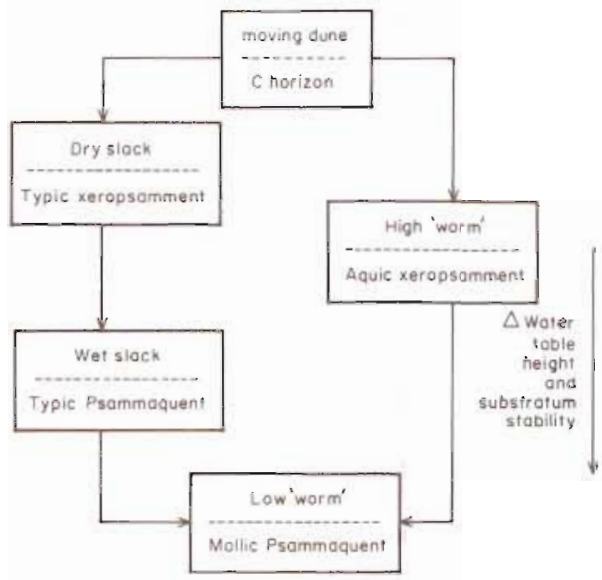

$$
\begin{aligned}
& \text { Morphoedaphic eiement } \\
& \hline \text { Soil classification }
\end{aligned}
$$

Figure 7. Geomorphology and soil evolution in the mobile dune system of the Doñana National Park, S.W. Spain.

psammaquents). The evolution of the soil and its relation to the geomorphology of the moving dunes system in Doñana National Park is shown in Fig. 7.

\section{References}

Allier, C., González-B. F. \& Ramírez, L. (1974). Mapa Ecológico de la Reserva Biológica de Doñana. CSIC. Sevilla. $14 \mathrm{pp}$.

Allier, C., García, F., Ramírez, L. \& Torres, A. (1975). Dynamique actuelle et vegetation du systeme littoral de Doñana (Golfe de Cadix). C. R. Societé Biogeographique de Francé, 440-442: $95-111$.

Apcarián, A. (1983). Evolución geomorfológica y edafológica de las arenas móviles del Parque Nacional de Doñana (España). Monografía (CEBAC). 100 pp.

Clemente, L. \& Siljeström, P. (1989). Les facteurs ecologiques de la pedogenese dans la Reserve Biologique de Doñana: le cadre de l'evolution. du sol. Cahier ORSTOM, Série Pedologie.

Davies, J. L. (1980). Geographical Variation in Coastal Development. London: Longman. 211 pp.

Duchaufour, Ph. (1975). Manual de Edafologia. Barcelona : Toray-Masson. 476 pp.

Figueroa, M. E. (1976). Ecología del pino en el Parque Nacionall de Doñana. Master's Thesis (Ecology Department), Sevilla University. 96 pp.

García-Novo, F., Ramírez, L. \& Torres, A. (1975). El sistema de dunas de Doñana. Naturalia Hispanica (ICONA.), 5: $56 \mathrm{pp}$.

Granados, M. (1981). Historia ecologica de Doñana. Monografia, Ecology Department, Seville University. 30 pp.

Hoyt, J. H. (1965). Air and sand movement to the lee of the dunes, Sedimentology, 7: 137-145.

McKee, E. D. (1979). A study of global sand seas. Geological Survey Professional Paper, No. 1052. $429 \mathrm{pp}$.

Ménanteau, L. (1981). Les Marismas du Guadalquivir. Exemple de transformation d'un paysage alluvial au cours du Quaternaire récent. Doctoral Dissertation, University of Paris, Sorbonne. 252 pp.

Ménanteau, L. \& Clemente, L. (1977). Nuevos datos sobre las relaciones entre la erosión costera y el ascenso del nivel marino en el sector Mazagón (Huelva)-Chipiona (Cádiz). Papel de la tectónica. 
Proceedings II Reunión Asociación Española para el Estudio del Cuaternario (AEQUA), Jaca, 177186.

Paul, K. H. (1944). Morphologie und Vegetation der Kurischen Nehrung. II. Flugsandes bis zum Wald. Nova Acta Leopoldina, 13: 215-238.

Pérez-Mateos, J. \& Ribas, M. (1961). Estudio de los sedimentos pliocenos y cuaterinarios de Huelva. Proceedings II Reunión Sedimentologí, Madrid (CSIC), 87-94.

Ranwell, D. S. (1972). Ecology of Salt Marshes and Sand Dunes. London: Chapman and Hall. 258 pp.

Siljeström, P. (1985). Geomorfología y Edafogénesis de las Arenas del Parque Nacional de Doñana. Doctoral Dissertation, Seville University. 515 pp.

Siljeström, P. \&: Clemente, L. (1987). Geological. History and Present-Day Geomorphology of Doñana National Park. Quaternary Research.

Siijeström, P., Clemente, L. \& Figueroa, M. E,. (1987). Localización de zonas de surgencia del nivel freático a través del estudio edáfico. Proceedings VII Reunion Asociación Española para el Estudio del Cuaternario (AEQUA), Santander: 89-92.

Soil Survey Staff (1975). Soil Classification. A Comprehensive System. 7th Approximation. U.S. Department of Agriculture. $754 \mathrm{pp}$.

Subdirección General de Costas y Señales Marítimas, Tercera Jefatura Regional de Costas y PuertosSur (1977). Plan indicativo de usos del litoral de dominio púlico. Tramos de costa: Provincias de Huelva, Cádiz y Málaga. Dirección General de Puerios y Señales Marítimas (MOPU). 240.

Thomtwaite, W. C. (1948). An approach toward a rational classification of climate, Geographical Revue, 38: 55 .

Torres, A., Allier, C., Ramírez, L. \& García-Novo, F. (1977) Sistemas de dunas. prospección e inventario de Ecosistemas. Monografía (ICONA), 18: 195-224.

Vanney, J. R. (1970). L’hydrologie du Bas Guadalquivir. Casa de Velázquez E Instituto de Geōgrafia Aplicada Alonso de Herrera (CSIC, Madrid). 176 pp.

Vanney, J. R. \& Ménanteau, L. (1979). Types de reliefs littoraux et dunaires en Basse Andalousie (de la Ria de Huelva à l'embouchure dù Guadalquivir). Melanges de la Casa de Velázquez, 1.5:5-52.

Vela, A. (1984). Estudio preliminar de ía hidrogeología e hidrogeoquímica del sistema de dunas móviles y flecha litoral del Parque Nacional de Doñana. Masters Thesis, Complutense University, Madrid. $221 \mathrm{pp.}$

Zazo, C. (1980). El cuaternario marino-continental y el límite plio-pleistoceno en el litoral de Cádiz. Doctoral Dissertation, Complutense University, Madrid. 436 pp. 